\title{
Test-tube babies, 1981
}

\author{
R.G. Edwards*
}

THIS year should prove a turning point for the birth of children by the fertilization of human eggs in vitro. Between 15 and 20 such babies will be born in approximately equal numbers in the United Kingdom and Australia, and there will be one or two elsewhere. These methods will be introduced in many countries, primarily to alleviate human infertility. Fundamental aspects of human conception will be analysed and increasing debate will presumably be given to genetic engineering. This is, therefore, an appropriate time to assess the relevant clinical and scientific issues raised by this work ${ }^{1}$.

\section{The first essential: timing of ovulation}

I will first discuss the methods involved in timing ovulation for the collection of preovulatory oocytes.

Harvesting preovulatory oocytes is the first of several steps essential for obtaining human embryos. They must be collected during their final stages of maturation just before ovulation occurs, when meiosis is advanced and cortical granules have established the defence against polyspermy. Follicular growth and ovulation must be regulated by endocrine therapy, or natural ovulation must be closely predicted during the menstrual cycle.

The regulation of ovulation is undoubtedly easier. Several follicles can be primed using human menopausal gonadotropin (HMG) or clomiphene early in the menstrual cycle. An endogenous surge of luteinizing hormone (LH) will then induce ovulation. Alternatively, a single injection of human chorionic gonadotropin (HCG, 5,000 IU) can be given between days 11 and 14, according to the follicular response of each patient. Levels of urinary oestrogens of $80-100 \mu \mathrm{g}$ per day (refs 2,3 ), or follicular diameters of $1.5-2 \mathrm{~cm}$ measured by ultrasound ${ }^{4-6}$ are believed to be appropriate indications to inject $\mathrm{HCG}$. Ovulation can be induced at any desired time of day or night, a considerable help in organizing laboratory or surgical teams for oocyte recovery. Two or more preovulatory oocytes can be collected from many patients, another advantage of stimulating the ovary.

There may be problems to offset these advantages. Wide variations exist in the rate of growth of individual follicles in each patient, revealed by the different levels of sterioids in follicular fluids ${ }^{7}$ and by variations in embryonic growth when superovulation techniques are applied to animals. Some patients fail to respond to clomiphene. Others produce increasingly large amounts of oestrogens as several follicles grow, and their endogenous LH stimulation can also distort the menstrual cycle, inducing a short luteal phase and a disorganized endometrium, both incompatible with establishing pregnancy ${ }^{12}$. An average of eight cycles of treatment with clomiphene is needed for oligomenorrhoeic women to conceive naturally ${ }^{3}$. Such disadvantages may be greater with

Between fifteen and twenty babies will be born this year after the in vitro fertilization of human eggs. Many of the essential steps now have high rates of success, including the recovery of preovulatory oocytes, and fertilization and embryo cleavage in vitro. Implantation of the embryo following its replacement in the mother remains the major difficulty. Some implications of the work are discussed.

surge stimulates ovulation. A difficult situation occurs in patients with moderate or high levels of oestrogens and no endogenous surge of LH (Fig. 1). As in other tissues ${ }^{8-11}$, clomiphene may have depleted cytoplasmic oestrogen receptors in the pituitary gland of such patients over several days, so preventing the LH surge in response to rising levels of oestrogens. HCG must be given at some arbitrary time, before follicles become atretic, yet while it is uncertain if the patient will have her own endogenous LH surge. Ovarian

\section{HMG than with clomiphene.}

The alternative is to monitor the approach of ovulation during the natural menstrual cycle, and then aspirate the single preovulatory oocyte. This method was used for the conception of the first child by fertilization in vitro ${ }^{12}$, and is widely used in our practice today. Plasma or urinary oestrogens are used to assess follicle growth, and the onset of the LH surge at mid-cycle provides a warning of the approach of ovulation.

The disadvantages are obvious. There is

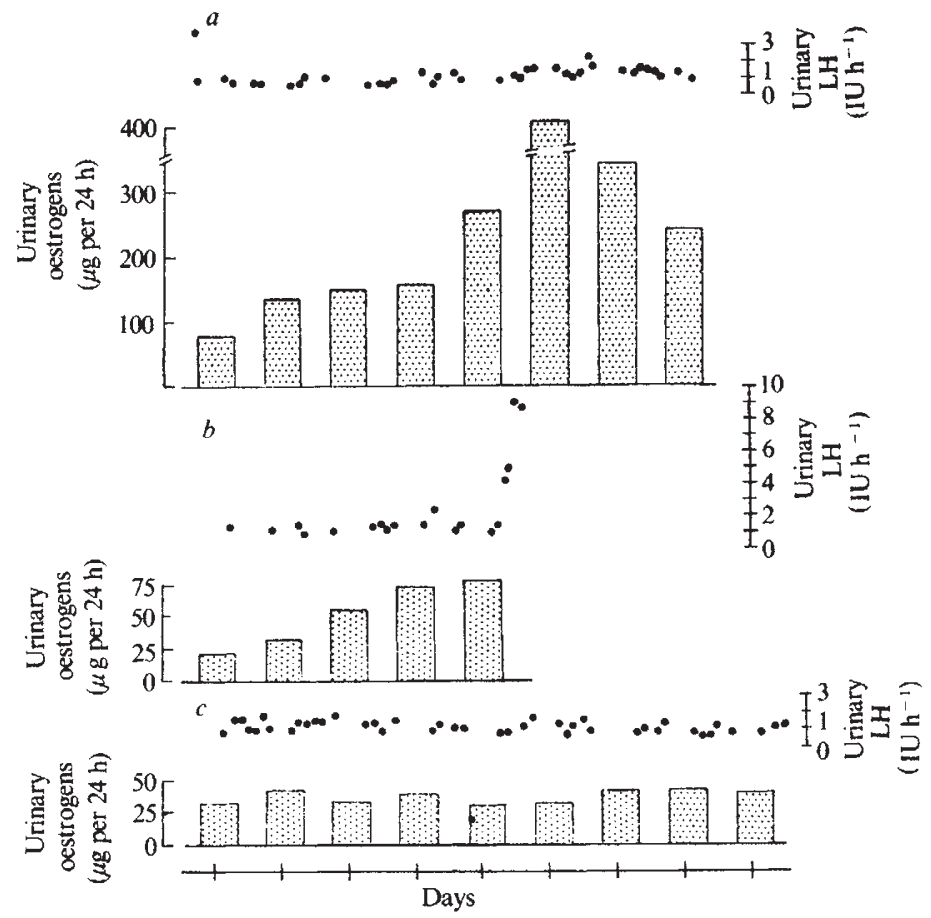

Fig. 1 Response of patients to clomiphene. $a$, l.evels of urinary oestrogens rose considerably, and then fell in the absence of an endogenous LH surge. $b$, Rising levels of urinary oestrogens followed by surge of L.H in urine. $c$, No response in urinary oestrogens and no surge $[$. , Urinary oestrogens; $\bullet$, urinary L.H, measured by the Hi-Govanis kit. 
Table 1 Aspiration of oocytes from preovulatory follicles

\begin{tabular}{|c|c|c|c|}
\hline & $\begin{array}{c}\text { Natural } \\
\text { cycle* }\end{array}$ & $\begin{array}{l}\text { Natural and } \\
\text { clomiphene } \\
\text { cycle }^{20}\end{array}$ & $\begin{array}{c}\text { Clomiphene } \\
\text { cycle }^{6}\end{array}$ \\
\hline No. of patients & 122 & - & - \\
\hline No. with accessible ovaries & 109 & - & - \\
\hline No. of preovulatory follicles aspirated & 109 & 172 & 107 \\
\hline No. (and $0 \%$ ) of oocytes collected & $\begin{array}{c}95 \\
(88 \%)\end{array}$ & $\begin{array}{c}110 \\
(64 \%)\end{array}$ & $\begin{array}{c}96 \\
(89 \%)\end{array}$ \\
\hline
\end{tabular}

*Recent series of 122 patients in Bourn Hall, Cambridge. Their average age was $33.9 \mathrm{yr}$. usually only one preovulatory oocyte, and any pathological conditions in the ovary or abdomen will limit the chances of collecting it. The LH surge is less predictable than an injection of HCG, hence more difficulty arises in organizing laboratory and clinical staff to collect the oocyte. Some difficulties have proved less than feared. Repeated blood sampling may provide a reliable guide for assaying $\mathrm{LH}^{6,13-15}$, but is unnecessary, because urine

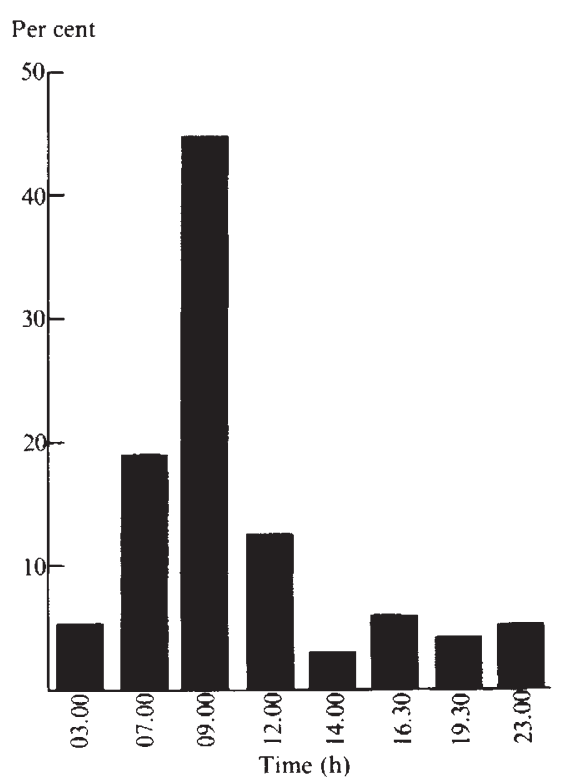

Fig.2 Diurnal rhythm in the onset of the urinary LH surge in women. The time shows the initial increase in levels of $1 . \mathrm{H}$ which was followed by a sustained rise (see Figs $1 b$ and 3).

samples are suitable for rapid assays of LH using the kit Hi-Gonavis (Mochida Pharmaceuticals) ${ }^{12}$ and for oestrogens. Fortunately, the LH surge begins in early morning in almost three-quarters of the women (Fig. 2), which is most convenient for the collection of preovulatory oocytes $24-28 \mathrm{~h}$ later. This 'critical period' in the $\mathrm{LH}$ surge in women resembles the situation ponent must modify the feedback effects of ovarian oestrogens and LH releasing hormone on the pituitary gland ${ }^{18}$. If women discharge their $\mathrm{LH}$ at other times of day, their oocytes must sometimes be aspirated less than $24 \mathrm{~h}$ later and cultured in

Fertility may be higher during the natural cycle than after ovarian stimuin rats ${ }^{16,17}$, and its distinct diurnal comvitro to complete maturation. lation, an obvious advantage in establishing pregnancy. Several surveys have revealed a 1 in 4 chance of pregnancy during unprotected intercourse in any menstrual cycle, but even this low rate may be higher than during induced cycles. Clomiphene may be indicated in patients with irregular or prolonged cycles.

\section{Aspiration of oocytes}

A double aspirating needle or two separate needles are used, one channel being used for aspiration and the other to flush out the follicle if the oocyte is not collected ${ }^{19,20}$. The flushing solution may contain heparin, to prevent clotting within the follicle.

The highest rates of collection are achieved $32 \mathrm{~h}$ after the injection of $\mathrm{HCG}$, or $26 \mathrm{~h}$ after the rise of $\mathrm{LH}$ in urine (Table 1). It is essential to time the onset of ovulation correctly. Should HCG be given after an endogenous surge of $\mathrm{LH}$, ovulation may occur before aspiration begins. Diurnal rhythms in tonic $\mathrm{LH}$ release, sometimes reaching low surge levels over a few hours, can confuse the correct timing of the LH surge (Fig. 3). Pelvic adhesions, hydrosalpinx, cystic follicles, endometriosis and other ovarian conditions impair the collection of oocytes, and preliminary laparoscopy may be required to alleviate these conditions. If the ovary is accessible, oocytes can be collected during the natural cycle from almost $90 \%$ of patients, laparoscopy being completed within a few minutes (Table 1). None of our patients had ovulated when laparoscopy was performed, and each of them had a large preovulatory follicle.

Preovulatory oocytes can be identified quickly. They are embedded in a viscous follicular fluid, to a diameter of $0.5 \mathrm{~cm}$ or more and can be seen by eye ${ }^{2}$. The viscosity of the cumulus mass serves as a guide to the stage of maturity of the oocyte. A few hours in culture in the presence of some follicular fluid helps to complete maturation, especially in those deliberately collected less than $26 \mathrm{~h}$ after the LH rise, which appear 'unripe'.

\section{Fertilization and cleavage in vitro}

Provided there are no pathological conditions in the husband's spermatozoa, almost $90 \%$ of the preovulatory oocytes aspirated during the natural cycle can be fertilized in vitro (Table 2). The conditions of culture are rapidly becoming standardized $^{3,6,7,12}$. Simple media are used, including Earle's solution with pyruvate, a medium designed to support mouse embryos in vitro ${ }^{21,22}$, and Ham's F10, each supplemented with serum albumin or homologous human serum $(7.5-8.6 \%)$. We prefer Earle's solution containing pyruvate, with serum from each patient (Table 3) ${ }^{12}$. Sperm numbers vary between $10^{5}$ and $10^{6}$ per $\mathrm{ml}$, or between 1 and $5 \times$ $10^{5}$ living spermatozoa per $\mathrm{ml}$. Droplets of medium held under paraffin oil or small culture tubes can be used for fertilization. Our present practice is to begin fertilization in droplets of medium under oil, adding $1.5-2 \times 10^{5}$ living spermatozoa per $\mathrm{ml}$ between 3 and $4 \mathrm{~h}$ after aspiration of oocytes; the oocytes are placed in tubes some hours later when most of their cumulus cells have been shed ${ }^{12}$.

The oocytes are fertilized within a few hours. Some have been fertilized following a re-insemination $48 \mathrm{~h}$ later and grew normally to the eight-cell stage (J.M. Purdy and R.G.E., unpublished). Conditions such as spermagglutination, viscous seminal plasma and erratic sperm movement reduce the chances of fertilization (Table 2). Almost all eggs are monospermic, indicating that the block to polyspermy is efficient $t^{3,6,23}$.

Most embryos cleave normally. They tolerate a wide variety of culture media, similar to those used for fertilization. Serum is almost universally added; in our work, we use $15 \% \mathrm{v} / \mathrm{v}$ of homologous serum $^{12}$. Cleavage times are remarkably similar despite the varying concentration of energy sources in different media (Table 3). There have been occasional reports of cell fragments in cleaving eggs, although similar conditions have been found in embryos flushed from the reproductive tract and may not be pathological ${ }^{24,25}$. Many embryos grow to morulae and
Table 2 Fertilization of human eggs in vitro

\begin{tabular}{lccc}
\hline & Patients with occluded oviducts & $\begin{array}{c}\text { Patients with } \\
\text { idiopathic } \\
\text { infertility }\end{array}$ \\
\cline { 2 - 4 } Total no. patients & Bourn Hall* & Melbourne & - \\
No. with pathological conditions: & 95 & - & - \\
Spermagglutination cells or debris in semen & 5 & - & - \\
Abnormal movement of spermatozoa & 3 & - & - \\
Viscous seminal plasma & 1 & 40 & $35 \%$ \\
Remainder & 86 & $37(92 \%)$ & - \\
No. (and \%) fertilized & $76(88 \%)$ & & - \\
\hline
\end{tabular}

*Recent survey of 122 patients (see Table 1). 
blastocysts, and escape from the zona pellucida in vitro ${ }^{3,6}$, although some apparently develop abnormally during these later stages of growth ${ }^{6}$. The fastestgrowing embryos are apparently the most successful in establishing pregnancy ${ }^{6,26}$. Cine films of cleavage with IR photography may enable embryos to be examined for their nuclear structure before they are replanted in the mother ${ }^{27}$.

\section{Replanting embryos}

Implantation is the most difficult and unpredictable stage. In animals, rates of implantation are high when embryos are replaced surgically $(>70 \%)$, but lower if replaced non-surgically via the cervix $(\sim 50 \%)^{28,29}$. Almost all human embryos have been replaced transcervically, and approximately one-quarter of them have

\begin{tabular}{|c|c|c|c|}
\hline \multicolumn{4}{|c|}{$\begin{array}{l}\text { Table } 3 \text { Composition of the media used for fertilization } \\
\text { and cleavage of human eggs in vitro }\left(\mathrm{g} \mathrm{I}^{-1}\right)\end{array}$} \\
\hline & $\begin{array}{l}\text { Modified } \\
\text { Earles }^{12}\end{array}$ & $\begin{array}{l}\text { Media for } \\
\text { mouse } \\
\text { eggs }^{21,22}\end{array}$ & $\begin{array}{l}\text { Ham's } \\
\text { F10* }\end{array}$ \\
\hline $\mathrm{CaCl}_{2} 2 \mathrm{H}_{2} \mathrm{O}$ & 0.2649 & - & 0.441 \\
\hline $\mathrm{KCl}^{2}$ & 0.400 & 0.356 & 0.285 \\
\hline $\mathrm{MgSO}_{4} \cdot 7 \mathrm{H}_{2} \mathrm{O}$ & 0.200 & 0.294 & 0.1527 \\
\hline $\mathrm{NaCl}$ & 6.800 & 5.140 & 7.400 \\
\hline $\mathrm{NaH}_{2} \mathrm{PO}_{4} \cdot 2 \mathrm{H}_{2} \mathrm{O}$ & 0.1583 & - & - \\
\hline $\mathrm{Na}_{2} \mathrm{HPO}_{4}$ & - & - & 0.156 \\
\hline $\mathrm{KH}_{2} \mathrm{PO}_{4}$ & - & 0.162 & - \\
\hline $\mathrm{NaHCO}_{3}$ & 2.1 & 1.9 & 1.2 \\
\hline Ca lactate & - & 0.527 & - \\
\hline Na pyruvate & 0.011 & 0.025 & 0.110 \\
\hline Glucose & 1.000 & 1.000 & 1.100 \\
\hline $\begin{array}{l}\text { Na lactate } \\
\quad(60 \% \text { syrup })\end{array}$ & - & $3.7 \mathrm{ml} \mathrm{l}^{-1}$ & - \\
\hline
\end{tabular}

Embryos growing most rapidly are two-cell by $21 \mathrm{~h}$ after insemination, four-cell at $40 \mathrm{~h}$, and eight-cell at 44-54 h (refs 3, 23)

*Also contains $\mathrm{CuSO}_{4}, \mathrm{FeSO}_{4}, \mathrm{ZnSO}_{4}$, amino acids, etc.

implanted in some series (Table 4). Embryos might be best replaced during the evening ${ }^{12}$, because the spontaneous contractility of the human uterus is lower at night $^{30,31}$. Disorders in the luteal phase, including progesterone deficiency and a short luteal phase, could preclude implantation (Table 4). Some implanted embryos live for only a short time after the expected return of menstruation, and are identified by a transitory rise in HCG $\beta$ (ref. 3) (Table 4).

Why do so few embryos implant? Perhaps $20 \%$ or thereabouts is all that can be expected, since it is similar to the incidence of natural human fertility reported in serval surveys. This view seems to be pessimistic. Some embryos may be lost or infected if there are difficulties in passing a catheter through the internal os. An outer metal cannula can be useful in such cases, but pregnancy rates are lower (Table 4). A Teflon catheter with a smooth tip and side aperture evidently passes easily through the internal ${ }^{6}{ }^{6}$, but may require the use of a tenaculum on the cervix. Implantations have occurred after replacing all stages between the two-cell and blastocyst, but there are insufficient data as yet on the optimal stage for replacement ${ }^{26}$.

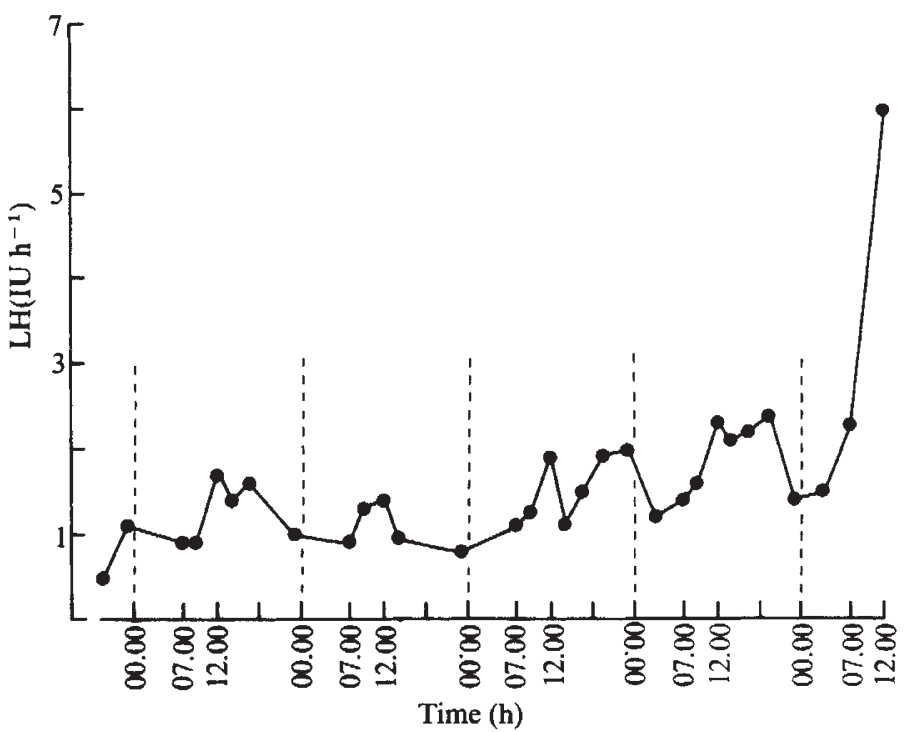

Fig. 3 Diurnal variations in the levels of urinary LH in women. 'Tonic' levels rise each morning, then decline. The $\mathrm{LH}$ surge began during the morning in this patient.
Physiological disorders might prevent replacement could invoke discharges of prolactin, and a catheter passed through the uterine cavity may invoke a premature decidualization of the endometrium. Slight myometrial contractions could expel embryos soon after their replacement and might be inhibited using $\beta_{2}$-mimetics ${ }^{30,31}$. Restricting the volume of medium might encourage implantation $(0.03-0.10 \mathrm{ml}$ are used at present). Surgical transfer might circumvent these problems, but a second anaesthesia will be needed soon after that used for oocyte recovery, and the myometrium and endometrium will undoubtedly bleed when a needle is passed through them. In rhesus monkeys, 11 out of 15 embryos replaced surgically in the oviduct, and 2 of 8 replaced in the uterus developed to advanced stages of gestation ${ }^{32}$.

\section{Growth of human fetuses after replacement in the mother}

At least 12 children have been born after fertilization in vitro, 3 in the initial series in implantation. Vaginal distension during
Oldham $^{33}, 7$ in Australia ${ }^{6,34}$, and 2 recently in the United Kingdom. Two of these were born prematurely at approximately 20 weeks, soon after amniocentesis. The children have been healthy, although a male twin required corrective surgery, and several current pregnancies appear to be progressing normally ${ }^{6,26}$. Details of all pregnancies are being recorded in an international register to evaluate any risks to the fetuses and the causes of abortion or fetal death.

Between one-quarter and two-fifths of the fetuses arising from fertilization in vitro die in utero, mostly in the first trimester. Maternal age (late thirties and early forties) may be a disposing factor in some cases. One dead fetus was triploid ${ }^{33}$, the others have not been karyotyped. Triploidy may not be serious quantitatively, as the vast majority of fertilized eggs are monospermic. Most triploid fetuses arising during fertilization in vivo are caused by dispermy, fewer being due to fertilization by a diploid spermatozoon or cleavage errors in the embryo ${ }^{35}$. Nor
Table 4 Pregnancies after replacing human embryos transcervically (same group of patients as in Tables 1 and 2)

\begin{tabular}{|c|c|c|}
\hline No. of patients & $\begin{array}{c}\text { Single catheter } \\
51\end{array}$ & $\begin{array}{l}\text { Double catheter } \\
\qquad 23\end{array}$ \\
\hline \multicolumn{3}{|l|}{ No. with deficient luteal phases: } \\
\hline Short luteal phase & $2 *$ & 0 \\
\hline Progesterone deficiency $†$ & 1 & 3 \\
\hline \multicolumn{3}{|l|}{ No. with delayed return to menstruation $\ddagger$ : } \\
\hline Brief elevated levels of $\mathrm{HCG} \beta$ & $2\}(9.8 \%)$ & 0 \\
\hline Brief elevated levels of $\mathrm{HCG} / \mathrm{LH}$ & $3 \int_{1}(9.0 \%)$ & 3 \\
\hline No. pregnant 4 weeks after replacement & $12(23.1 \%)$ & $2(8.7 \%)$ \\
\hline
\end{tabular}

* Luteal phase of 12 days or less; these patients had luteal phases of 5 and 12 days, respectively, one also having progesterone deficiency.

t These patients had between 0.4 and $2.7 \mathrm{ng} \mathrm{ml}^{-1}$ on days 7 or 8 of the luteal phase.

† Some other patients showed a delayed return to menstruation but no evidence was found of elevated HCG $\beta$ or $\mathrm{HCG} / \mathrm{LH}$. 
Table 5 Results on a recent series of 122 patients with tubal occlusion

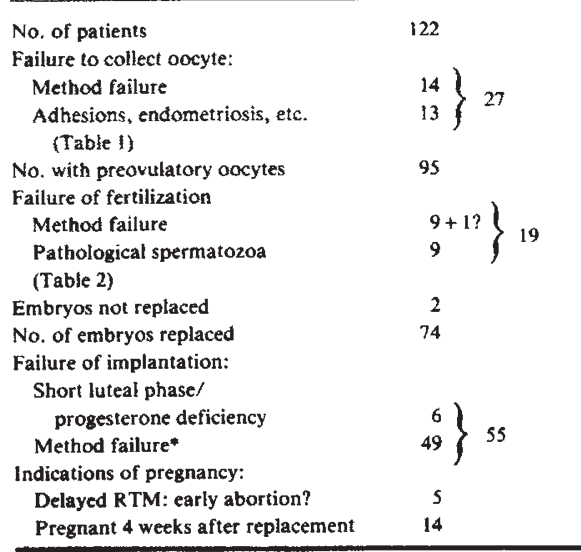

The natural menstrual cycle was monitored. RTM, return to menstruation.

*See Table 4.

should trisomy be more frequent after fertilization in vitro. Most human trisomies arise during the first meiotic division of the oocyte 36,37 , a stage which is virtually complete before the oocytes are aspirated. Others arise during the second meiotic division, that is, after fertilization, or during cleavage of the embryos, but there is no record of their incidence in vitro. Amniocentesis should be performed on all fetuses arising through fertilization in vitro, if the parents agree, until the risks of trisomy have been assessed.

Some fetuses may die in utero through physiological or embryological factors associated with fertilization in vitro. These could include damage to the uterine wall during replacement of the embryos, the introduction of cervical flora into the uterine cavity and the implantation of the embryo low in the uterine canal ${ }^{3}$. Short or deficient luteal phases arising after ovarian stimulation, or through the withdrawal of too many granulosa cells from the preovulatory follicle occur in very few patients (see Table 4$)^{38}$. Abnormal embryonic differentiation in vitro might have led to the transitory secretion of $\mathrm{HCG}$ in some patients, as the fetus developed into a 'blighted ovum' or trophoblastic vesicles, resulting in its early death. Such conditions arise following conception in vivo 39.40

\section{Genetic engineering}

Arguments sometimes raised against the introduction of fertilization in vitro into clinical practice involve the possibility of genetic engineering - chimaeras, hybrids and cloning embryos. These issues are quite distinct from the alleviation of infertility. Three cloned mice have been born, using nuclei from blastocysts ${ }^{41}$, and others after the use of nuclei from the embryonic ectoderm and proximal endoderm of 7-day mouse embryos, showing that the developmental potential of nuclei from earlier embryos is retained in these cell types ${ }^{42}$.
The thought of cloned human embryos identical to a pre-existing individual is not attractive. Yet, in a sense, uniparental human embryos largely similar to the father already exist. Hydatidiform moles are the remains of diploid androgenetic fetuses, in which the trophoblast proliferates over several weeks to form large grape-like vesicles. Such fetuses evidently arise due to the expulsion of the female pronucleus from the fertilized egg $^{43-46}$. The sperm chromosomes are doubled and the embryo expresses paternal chromosomes only. Rare hydatidiform moles may even retain much of the father's heterozygosity, since they could arise from a diploid spermatozoon. The reason androgenetic embryos undergo hydatidiform changes is not understood. Perhaps the embryonic cells die early, or the mother 'rejects' a fetus lacking her own antigens ${ }^{46}$; nevertheless, androgenetic mouse embryos develop normally to full term ${ }^{47}$. Human gynogenones could also arise through similar processes involving expulsion of the male pronucleus from the egg, although no searches have yet been made for them before or after birth. Uniparental embryos could arise through delayed syngamy and an enlarged pronucleus, seen in two human eggs fertilized in vitro.

Subtle forms of genetic engineering have been introduced. DNA fragments containing the gene for human insulin were injected into pronucleate mouse eggs, and the gene was identified in tissues of fetuses at the 18th day of pregnancy ${ }^{42}$. The DNA evidently replicated and was inserted into

1. 3rd World Congress of Human Reproduction, Berlin (Excerpta Medica, Amsterdam, 1981).

2. Edwards, R.G. \& Steptoe, P.C. J. Reprod. Fert. Suppl. 22, 121 (1975); Lancet I, 683 (1970)

3. Edwards, R.G. Conception in the Human Female (Academic, London, 1980).

4. Kratochwil, A. Urban, G, \& Frjedrich, F. Ann Chir. Gynaec. Fenniae 61, 211 (1972)

5. de Crespigny, L.J. Ch., O'Herlihy, C., Hoult, I.J. \& Robinson, H.P. Fert. Steril. 35, 25 (1981).

6. Trounson, A.O. et al. 3rd World Congress of Human Reproduction, Berlin (Excerpta Medica, Amsterdam, 1981)

7. Fowler, R.E., Edwards, R.G. Walters, D.E., Chan, S.T.H \& Steptoe, P.C. J. Endocr. 77, 161 (1978)

8. Baudendistel, L.J., Ruh, M.F., Nadel, E.M. \& Ruh, T.S. Acta endocr. 89, 599 (1978).

9. Katzellenbogen, B.S. \& Ferguson, E. R. Endocrinology 97 1 (1975).

10. Watson, C.S., Medina, D \& Clark, J.H. Endocrinology 108,668 (1981)

11. Adashi, E.Y., Hsueh, A.J.W. \& Yen, S.S.C. J. Endocr 87, 383 (1980).

12. Edwards, R.G., Steptoe, P.C. \& Purdy, J.M. Br. J. Obstet. Gynec. 87, 737 (1980).

13. Frydman R Testart J \& Feinstein, M.C. 3rd World Congress of Human Reproduction, Berlin (1981).

14. Plashot, M., Mandelbaum, J. \& Cohen, J. 3rd World Congress of Human Reproduction, Berlin (Excerpta Medica, Amsterdam, 1981)

15. Mettler, L. 3rd World Congress of Human Reproduction Berlin (Excerpta Medica, Amsterdam, 1981).

16. Everett, J.W. \& Sawyer, C.H. Endocrinology 47, 198 (1950)

17. Everett, J.W. A. Rev, Physiol. 31, 383 (1969)

18. Knobil, E. Recent Prog. Horm. Res. 36, 53 (1980)

19. Lopata, A., Johnston, I.W.H., Houalt, I.J. \& Speirs, A.I. Fert. Steril. 33, $117(1980)$

20. Renou, P., Trounson, A.O., Wood, C. \& Leeton, J.F. Fert. Steril. 35, 409 (1981)

21. Brinster, R.L. in Reproductive Biology (eds Balin, H. \& Glasser, S.) (Excerpta Medica, Amsterdam, 1972).

22. Hopp P C \& Pits, J Biol. Reprod. 8, 420 (1973).

22. Hoppe, P. \&. Purdy, J.M. \& Steptoe, P.C. Am. J. Obstet. Gynec. (in the press)

24. Sundström, P., Nilsson, O. \& Liedholm, P. Acta obstet. the genome of the fetus, but there is no information as to whether it was transcribed. There is apparently no knowledge of the potential value of such treatments in preventing the expression of inherited conditions such as diabetes.

\section{Prospects}

Many children will soon be born after the fertilization of human eggs in vitro. We have established more than $\mathbf{4 0}$ pregnancies since resuming work during the past 9 months, and the majority are surviving. This is most encouraging for those couples who could not be offered any other form of corrective surgery and have so far been without effective treatment (Table 5). The method can be carried out several times on the same patient, and success rates should soon exceed some forms of oviductal surgery. If ovarian stimulation is used, 'spare embryos' may be available for embryological studies and one embryo has grown for 9 days in vitro until stage $5 a$ (ref. 3 ). The frozen storage of human embryos still appears to be distant. Some of the fathers were oligospermic, and patients with idiopathic (unexplained) infertility, hostile cervical mucus, incompetent cervix, antibodies against the zona pellucida, might also be helped. Complex disorders leading to the abnormal growth of pronuclei can be investigated ${ }^{48}$.

I thank Jean Purdy and Patrick Steptoe for their help at all stages of this work, and Simon Fishel for his comments on the manuscript.

\section{gynec scand 60, 109 (1981).}

25. Wramsby, H. \& Liedholm, P. 3rd World Congress of Human Reproduction, Berlin (Excerpta Medica, Amsterdam, 1981)

26. Edwards, R.G. Steptoe, P.C. \& Purdy, J.M. 3rd World Congress of Human Reproduction, Berlin (1981).

27. Hamberger, L. 3rd World Congress of Human Repro duction, Berlin (Excerpta Medica, Amsterdam, 1981).

28. Rowson, L.E.A. (ed.) Egg Transfer in Cattle (Commission of European Communities, Brussels, 1976).

29. Sreenan, J.N. Theriogenology, 9, 69 (1978)

30. Lundström, V., Eneroth, P., Granström, E. \& Swahn, K.-L. 3rd World Congress of Human Reproduction, Berlin (Excerpta Medica, Amsterdam, 1981).

31. Akerjund, M., Andersson, K.-E. \& Ingermarsson, I. Br. J. Obstet. Gynec. 83, 673 (1976).

32. Marston, J.H., Penn, R. \& Sivelle, P.C. J. Reprod. Fert 49, 175 (1977).

33. Steptoe, P.C., Edwards, R.G. \& Purdy, I.M. Br. J. Obstet Gynec. 87, $757(1980)$

34. Lopata, A. Nature 288, 642 (1980)

35. Jacobs, P.A. et al. Ann. hum. Genet، 42, 49 (1978).

36. Hassold, T.J. \& Matsuyama, A. Hum. Genet. 46, 285 (1978)

37. Niikawa, N., Merotto, E. \& Kajii, T. Hum. Genet. 40, 73 (1977)

38. Feichtinger, W., Kemeter, P., Szalay, S., Beck, A. \& Janisch, H. 3rd World Congress of Human Reproduction, Berlin (Excerpta Medica, Amsterdam, 1981).

39. Hertig, A.T. in Progress in Infertility (eds Behrman, J. \& Kistner, R.W.) (Little Brown, Boston, 1975).

40. Batzer, F.R. Schlaff, S., Goldfarb, A.F. \& Carson, S.L. Fert. Steril. 35, 307 (1981).

41. Illmensee, K. \& Hoppe, P.C. Cell 23, 9 (1981).

42. Illmensee, K. 3rd World Congress of Human Reproduction, Berlin (Excerpta Medica, Amsterdam, 1981).

43. Kajii, T. \& Ohama, K. Nature 268, 633 (1977).

44. Jacobs, P.A. Wilson, C.M., Sprenkle, J.A. Rosenheim, N.B. \& Migeon, B. Nature 286, 714 (1980).

45. Lawter, S.D. et al. Lancet ii, 580 (1979)

46. Surti, U., Szulman, A.E. \& O'Brien, S. Hum. Genet, 51, 153 (1979).

47. Hoppe, P.C. \& Illmensee, K. Proc natn Acad Sci. U.S.A. $74,56-57(1977)$

48. Trounson, A.O., Leeton, J.F., Wood, C., Webb, J. \& Kovacs, G. Fert. Steril. 34, 431 (1980) 